\title{
Mating system of the amazonian cichlid angel fish, Pterophyllum scalare
}

\author{
Cacho, MSRF. ${ }^{\text {** }}$ Yamamoto, $M E .^{\text {a }}$ and Chellappa, $S .^{\text {b }}$ \\ aPostgraduate Programme in Psychobiology, Department of Physiology, Universidade Federal do Rio Grande do Norte, \\ Av. Salgado Filho, 3000, Lagoa Nova, CEP 59072-970, Natal, RN, Brazil

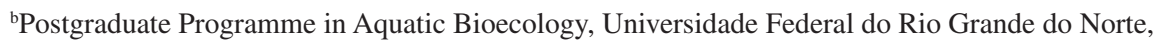 \\ Praia de Mãe Luiza, s/n, Via Costeira, CEP 59014-100, Natal, RN, Brazil \\ *e-mail: socorrocacho@ufrnet.br
}

Received June 10, 2005 - Accepted August 24, 2005 - Distributed February 28, 2007

(With 2 figures)

\begin{abstract}
The species, Pterophyllum scalare distinguishes itself by its breeding behavior, involving competition for territory, sexual partners, courtship and parental care. The purpose of this study was to identify the mating system adopted by this species of fish. Twenty males and twenty females were observed under semi-natural and experimental conditions to test the hypothesis of serial monogamy. Under semi-natural conditions, after the third breeding cycle, the couples changed mates. Under experimental conditions, the couples changed partners after the first breeding cycle. Under experimental conditions, mate recognition was investigated through the preference of the females, indicated by the time they spent with the males. The females were available or not for courtship from new males, depending on their aggressiveness or submission. The larger and more aggressive males obtained new mating opportunities while the submissive males were rejected by the females. The mated fish were aggressive towards intruders in the presence of the mate, protecting their pair bond. In the interval between breeding cycles, the couples did not display aggression towards intruders, confirming the hypothesis of serial monogamy. Best mate selection by the females and the opportunity of new matings for both sexes influenced the reproductive success of this species.
\end{abstract}

Keywords: Cichlidae, reproductive behavior, mate selection, serial monogamy.

\section{Sistema de acasalamento no ciclídeo amazônico, Pterophyllum scalare}

\begin{abstract}
Resumo
A espécie Pterophyllum scalare se destaca pela complexidade de seu comportamento reprodutivo, envolvendo competição por território e parceiros sexuais, corte, acasalamento e cuidado parental. Este trabalho teve como objetivo identificar o tipo de sistema de acasalamento adotado pelos peixes desta espécie. Vinte machos e vinte fêmeas foram observados nas situações seminatural e experimental para testar a hipótese de monogamia serial. Em situação seminatural, após o terceiro ciclo reprodutivo, os casais mudaram de parceiros, enquanto que, em situação experimental, os casais mudaram de parceiros a partir do primeiro ciclo reprodutivo. Em situação experimental foi investigado o reconhecimento do parceiro, pela permanência das fêmeas que se mostraram disponíveis ou não à corte de novos machos, em função da agressividade e submissão deles. Machos maiores e mais agressivos obtiveram novas oportunidades de acasalamento e machos submissos foram rejeitados pelas fêmeas. Os peixes acasalados foram agressivos a intrusos na presença do parceiro, protegendo a ligação do par. No intervalo entre os ciclos reprodutivos, os pares não mostraram agressão a intrusos, confirmando a hipótese de monogamia serial. A escolha do melhor parceiro pelas fêmeas e a oportunidade de novos acasalamentos para ambos os sexos influenciaram o sucesso reprodutivo desta espécie.
\end{abstract}

Palavras-chave: Cichlidae, comportamento reprodutivo, escolha de parceiro, monogamia serial.

\section{Introduction}

Monogamous animals establish short and long term relationships during one or more successive breeding seasons (Krebs and Davies, 1996). In monogamous pairs, the male contributes to the reproductive success of the couple by defending the territory where the female feeds or takes care of her offspring (Wickler and Seibt, 1985).

In fish, the pair bond usually endures for just one spawning and monogamy is maintained in only a 
small number of species, since the vast majority is polygamous (Takegaki and Nakazono, 1999). Among cichlids, some species are monogamous, for example Cichlasoma citrinellum, (Rogers, 1995) and Cichlasoma nigrofasciatum (Lampecht and Reblan, 1997).

The angel fish, Pterophyllum scalare Lichtenstein, 1823 has distinguished itself by the complexity of its reproductive behavior, involving competition for territory and sexual partners, courtship, mating and parental care. In this species, the couple is greatly involved with the offspring, mainly during the initial breeding phase (Cacho et al., 1999).

Angel fish, $P$. scalare couples could be considered monogamous, since the individuals tend to mate with a single partner. However, it is probable that they do not maintain a strict monogamy since the males tend to abandon the females (Cacho et al., 1999). The females demonstrate that they are available for courtship from other males, often mating sequentially with new partners. Thus, the objective of this study was to identify the type of mating system adopted by these fish, testing the hypothesis that the couples have serial monogamous relationships, with males often deserting their partners in search of other females for mating. Three predictions can be made from this hypothesis: the males may abandon the females with their offspring after mating; after deserting the females, the males may mate with other females; the females, when abandoned, protect their young until independence and may accept new mating partners in a new cycle.

\section{Materials and Methods}

The observations were made in the Ichthyology Laboratory of the Department of Oceanography and Limnology of the Federal University of Rio Grande do Norte, Natal, Brazil in 2003 and 2004.

\subsection{Acquisition and maintenance of the fish}

Twenty eight-month-old males and twenty females of the angel fish, P. scalare species from the Amazon Basin, acquired in an ornamental fish commercial establishment, were used in the study. In the laboratory, the fish were stocked in 1,000 L asbestos tanks. They were maintained at a temperature of around $27^{\circ} \mathrm{C}, \mathrm{pH}$ between 6.8 and 7.0 and dissolved oxygen ranging from 7.7 and $8.0 \mathrm{mg} . \mathrm{L}^{-1}$. Physical-chemical parameters such as $\mathrm{pH}$ and temperature were checked daily. The airing of tanks was done through a system of plastic hoses and an aerator. The fish were examined weekly to verify and prevent diseases. Diet corresponded to $5 \%$ of body weight and consisted of Artemia salina Linnaeus, 1758, and cichlid ration, fed daily ad libitum, and provided with constant aeration. Precautions were taken to minimize disturbance to the fish and the natural photoperiod of 6 to 18 hours was maintained in the laboratory.

After a 2 month acclimatization and maintenance period, the fish, which weighed between 9 and $30 \mathrm{~g}$ for the males and between 8 and $15.7 \mathrm{~g}$ for the females and total lengths ranging from 85 to $145 \mathrm{~mm}$ for the males and from 80 to $128 \mathrm{~mm}$ for the females, were selected for observation. Biometry was performed to record weight, height and total length of the fish used. The fish were considered small if their total length was less than $95 \mathrm{~mm}$; intermediate with a total length between 95 and $120 \mathrm{~mm}$ and large those whose length was greater than $120 \mathrm{~mm}$, in accordance with previous studies (Cacho et al., 1999; Chellappa et al., 1999a).

\subsection{Procedures}

The fish were observed under semi-natural and experimental conditions by the animal focal and sequence methods (Sabino, 1999).

\subsection{Testing under semi-natural conditions}

Breeding was observed in the laboratory under seminatural conditions, similar to those encountered in nature. In their natural habitat, these fish live along river margins in clear water with dense aquatic vegetation, and are usually found among the roots of these plants. In the laboratory, the fish were placed in a glass aquarium $(1.20 \times 0.58 \times 0.50 \mathrm{~m})$, with a bottom of crushed river stone and sand, adorned with different species of Amazonian aquatic plants, with large (Anubia sp. and Echinodorous amazonensis, Fasset) and narrow leaves, such as Valisneria gigas, Graebener and Elodia sp.

Ten angel fish specimens were used in this test: six males and four females of approximately 10 months of age. A greater number of males than females were used to stimulate mating competition.

The fish were maintained under semi-natural conditions for two months (from August to September) and observed for 30 days for 1 hour each day. Breeding of randomly-formed pairs was observed during one breeding cycle (a cycle of approximately 21 days, corresponding to the period between territory occupation and independence of the offspring). At the end of the first breeding cycle, the couples were marked by clipping their dorsal and pelvic fins so that by identifying the fish individually, the stability of the existing pair bond or the formation of new pairs can be observed. The same fish were monitored for five additional breeding cycles. The monitoring of the six cycles took place over a nine-month period.

\subsection{Testing under experimental conditions}

To investigate the stability of the pairs under experimental conditions, the fish were placed in glass aquariums where tests were performed to recognize the partner and the intruder.

\subsection{Mate recognition test}

Twelve males and six females were used to recognize the partners by the length of time spent by the female with a male. The fish were placed in six aquariums $(70 \times 40 \times 40)$ and six tests performed, each with six observations. Individuals that had formed pairs in a previous breeding cycle were used. In each aquarium the male that had already mated with the female during the 
first breeding cycle was placed along with a stranger. The males were observed under neutral conditions (a situation in which no territory had been established by either fish). The female was introduced after 48 hours.

Previous partners of intermediate size (total length between 95 and $120 \mathrm{~mm}$ ) were used in these tests, along with small male strangers (total length less than $95 \mathrm{~mm}$ ); previous partners with male strangers of the same size (total length between 95 and $120 \mathrm{~mm}$ ) and previous partners with larger male strangers (total length greater than $120 \mathrm{~mm}$ ) with $\mathrm{N}=6$ for each category. All the fish were at an optimal breeding age of less than 1 year.

The following behavior was observed: threatening (when the fish kept its head down, fins expanded and floor of the mouth retracted, bending its body towards the opponent); attacking (sudden movement towards the opponent); biting (the act of compressing or injuring the opponent with the teeth) retreating (when one fish distanced itself approximately $15 \mathrm{~cm}$ from the other); submission (when the fish retracted its fins, remained motionless, keeping its head up and displaying darker coloration); escape (when one fish stopped confronting the other and rapidly left the area) and female preference (defined by the time that a female remained motionless within a $10 \mathrm{~cm}$ radius of one of the males or swims side by side towards the substrate to spawn (Chellappa et al., 1999b).

\subsection{Intrusion test}

This test was applied to test the stability of the pair during the reproductive period and the response to intruders in the interval between breeding cycles. Six couples of angel fish with a previously established bond and twelve intruders (six males and six females) were used. Observations were performed in six glass aquariums $(70 \times 40 \times 40 \mathrm{~cm})$, each containing one couple. To test the stability of the bond, a male intruder was introduced and the reaction of each couple was observed. Subsequently, the male intruder was removed and substituted by a female intruder, with the reaction of the couple once again observed. The intrusions were repeated three times to investigate the behavior shown by the residents in both situations (couple with male intruder and couple with female intruder). Later, each couple was separated and a male intruder was introduced with the female resident, followed by a female intruder with the male resident in order to observe the behavior shown by the resident animals. The introductions were repeated three times to investigate the behavior of the residents in both situations (separated male with female intruder and separated female with male intruder). The behavior observed was: threatening, attacking, biting, distancing, submission, escape and female preference (of the female resident with the male resident and with the male intruder; of the male resident with the female resident and with the female intruder), all previously described.

\subsection{Statistical analysis}

The statistical tests were performed with SAS software (Howell, 1992), using analysis of variance
(ANOVA). Tukey's test and Student's t-test were used to identify differences between the treatments used.

\section{Results}

\subsection{Stability of the pairs under semi-natural conditions}

The results obtained under semi-natural conditions confirm the tendency of the couples to accept new mating partners. In this situation, $50 \%$ of the couples did not maintain the pair bond after the first breeding cycle. The remaining 50\% maintained the bond during the second and third breeding cycles. After the first breeding cycle, $50 \%$ of the males abandoned the females with their offspring. After the third cycle, none of the couples maintained the bond. All the males abandoned the females with their offspring and mated with other females. The females protected the larvae until they became independent and subsequently accepted new mating partners.

Under semi-natural conditions, only two of the six males observed mated five times, one managed to mate four times, another three times and two mated twice. Two of the females observed mated six times, one mated five times, another four times and two females, probably needed longer preparation time for a new egg-laying cycle, and as a result had fewer matings. The males that had fewer matings were those that had less success when competing for females.

\subsection{Stability of the pair under experimental conditions}

\subsubsection{Mate recognition test}

This test is not conclusive in affirming if the females recognize their mates or not. The criteria used by the females to remain with one of the males was the aggressiveness or submission displayed by the males and not the previous bond. During the test, the previous mates were more aggressive than the strangers, only when the latter were smaller. In this situation, aggression frequency of the previous mates was greater than that of the strangers with significant differences between them (ANOVA, t-test, $\mathrm{t}=8.08 ; \mathrm{p}<0.0001)$. When the previous mates and strangers were of equal size, they were equally aggressive. The differences related to the aggressiveness of the males were not significant (ANOVA, $\mathrm{t}$-test, $\mathrm{t}=0.86$; $\mathrm{p}=0.39$ ) However, when the previous mates were smaller, they were significantly less aggressive than the strangers (ANOVA, $\mathrm{t}$-test, $\mathrm{t}=3.34 ; \mathrm{p}=0.0019$ ).

A significant correlation was observed between the aggressiveness of the males and female preference (Pearson, $\left.r^{2}=0.4876 ; p=0.0001\right)$. Analyzing the comparisons between mean female preference for previous partners and smaller, equally sized and larger male strangers (Figure 1), it was observed that the females had a significantly greater mean preference for previous mates only when the male strangers were smaller (ANOVA, previous mates: $\mathrm{t}$-test: $\mathrm{t}=15.58$; $\mathrm{p}<0.0001$ ). When the male strangers were of equal size there were no significant differences in female preference (ANOVA, equal strangers: $\mathrm{t}$-test, $\mathrm{t}=0.52 ; \mathrm{p}=0.61)$. On the other 


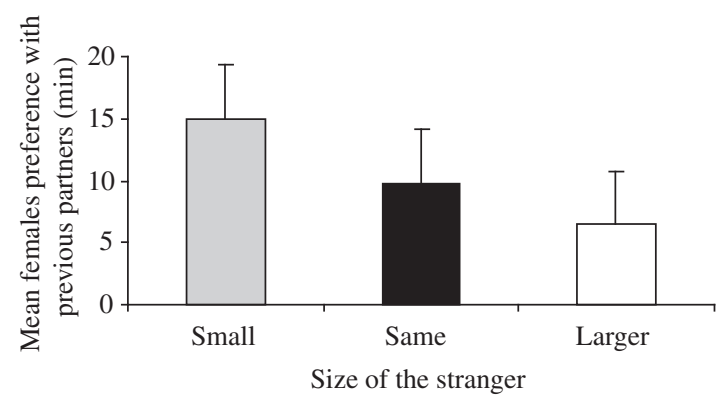

Figure 1. Mean and standard deviation of time (min) of females spent with the male during the recognition tests between the partner and smaller strangers: $p<0.0001$; of equal size; $\mathrm{p}=0.61$ and larger: $\mathrm{p}<0.0001$, using Tukey's test.

hand, when the strangers were larger, mean female preference for the strangers was significantly greater than that with previous partners (ANOVA, larger strangers: t-test $=-4.83 ; \mathrm{p}<0.0001)$.

We compared the mean frequencies of submission behavior displayed by the males during the mate recognition test with strangers of different sizes. It was observed that previous partners were only not submissive when the strangers were smaller. The submissive behavior in this case was recorded only for the strangers with significant differences in relation to the previous partners (ANOVA, $\mathrm{t}$-test, $\mathrm{t}=-3.83 ; \mathrm{p}=0.0005)$. However, when the previous mates and the strangers were of equal size, the previous partners were more submissive than the strangers with significant differences between them (ANOVA, t-test, $\mathrm{t}=2.30 ; \mathrm{p}=0.024$ ). Moreover, when the previous partners were smaller than the strangers, they were significantly more submissive (ANOVA, t-test, $\mathrm{t}=4.45$; $\mathrm{p}<0.0001)$.

Data analyses of the results of recognition tests with smaller, equal sized and larger mates showed significant correlation, inversely proportional between female preference and submissive behavior of the males (Pearson, $r=-0.6604 ; \mathrm{p}<0.0001)$. The best predictor of the length of time that a female stays away from the male was his display of submissiveness.

\subsubsection{Intruder test}

The intruder test showed the reaction of the couples to intruders during breeding. At the beginning of the reproductive cycle, it was observed that the females stayed a significantly longer mean period of time with their mates than they did with intruder males (ANOVA, t-test, $t=12.99 ; p<0.00001)$, Figure 2). The males also stayed a significantly longer mean period of time with their mates than they did with female intruders (ANOVA $<\mathrm{t}$-test, $\mathrm{t}=$ 2.80; $\mathrm{p}<0.00839$ ).

The aggressiveness of the males when faced with intruders of either sex during the breeding cycle was greater than that displayed by the females, with mean

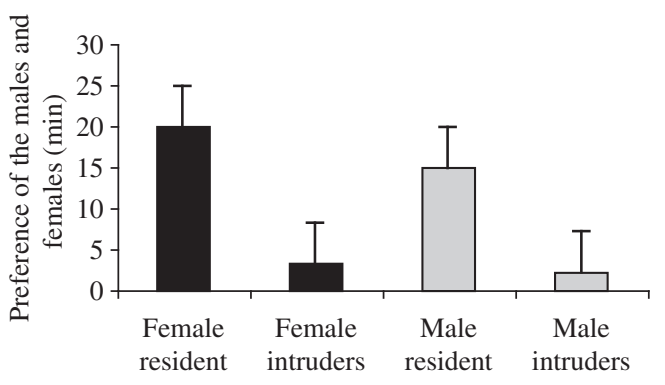

Conditions of the males and females

Figure 2. Preference (mean and standard deviation) of the males and females (minutes spent with the opposite sex) in the presence of intruders: males faced with female intruders $(p=0.00839)$ using Student's t-test; females faced with male intruders ( $\mathrm{p}<0.00001)$, using Student's t-test.

values for aggressiveness equal for intruders of both sexes (ANOVA, t-test, $t=0.3063 ; p=0.7612$ ). The females were as aggressive as the males in the presence of other females, with mean values significantly different from those observed in the presence of males (ANOVA, $\mathrm{t}$-test, $\mathrm{t}=-3.414 ; \mathrm{p}=0.0016)$. At the end of the breeding cycle, there was no significant correlation between the aggressiveness of couples faced with intruders (male or female) and during the interval between the cycles the pairs were not aggressive towards intruders of the opposite sex when separated.

\section{Discussion}

The results showed that angel fish couples adopted serial monogamy, both under semi-natural and experimental conditions. Under semi-natural conditions, the fish mated and remained with their partners for one to three breeding cycles. From the third cycle, the pair bond was not maintained and both fish sought new mating partners. Under experimental conditions, the couples did not maintain the pair bond beyond the second breeding cycle, acquiring new partners. In serial monogamy, as described by Gould and Gould (1989), after investing in the offspring, the partners seek new mating opportunities. The results of this study are in accordance with this description.

Under semi-natural conditions, the duration of the pair bond up to the third cycle was possibly motivated by the presence of the offspring and by the need to protect them. Abandoning the females must be considered as a male strategy to increase their reproductive success, by a greater number of matings. The females after independence of the young, also accept new courtship and mating. However, under no circumstance was a male seen mating with more than one female or a female accepting the courtship of more than one male.

In angel fish, the levels of aggression towards intruders suggest that there is a bond between the pair. 
However, the attributes of the male may motivate a female to substitute her partner for another more suitable one at the end of the breeding cycle. Under experimental conditions, the females rejected their partners when they were offered better mating opportunities. In this case, mate choice was influenced by the body size and aggressiveness of the males. The submissive males were rejected by the females and consequently did not manage to maintain the pair bond. It is likely that there is a possibility of pairing with affected female breeding decisions. A better mate choice on the part of the females must be considered adaptative, since these mates bear genes that may improve the viability of their descendents (Nicoleto, 1995).

Pair stability in the angel fish species was also tested by the resident-intruder paradigm. The aggressive response of the mated fish towards intruders at the beginning of the breeding cycle may have been stimulated by the situation of intense sexual competition and the presence of the partner can be considered as a triggering and intensifying factor of the aggression displayed by these fish towards intruders. These results are supported in studies by Huntingford (1979) of three-spined stickleback, Gasterosteus aculeatus and by Walter and Trillmich (1994) of the cichlid Lamprologus ocellatus. Aggressiveness towards intruders at the onset of the breeding cycle may also be understood as a protective measure for the pair bond, maintained by the pressure of the presence of the partner, since during the interval between breeding cycles and when the couples were separated, there was no aggression towards intruders, confirming the hypothesis of serial monogamy in these fish.

The contribution of the males is important for breeding success in angel fish, since these fish inhabit very competitive environments, where it is extremely difficult for the females to protect the eggs by themselves. Additionally, males that cooperate with parental care are preferred by females and are thus successful in breeding.

\section{References}

CACHO,MSRF.,YAMAMOTOME. andCHELLAPPA,S., 1999. Comportamento reprodutivo do acará bandeira, Pterophyllum scalare (Osteichthyes, Cichlidae). Rev. Bras. Zool, vol. 16 , no. 1, p. 653-664.

CHELLAPPA, S., YAMAMOTO, ME., CACHO, MSRF. and HUNTINGFORD, FA. 1999a. Prior residence, body size and the dynamics of territorial disputes between male freshwater angelfish. Journ. Fish Biol., vol. 55, no. 6, p. 1163-1170.

CHELLAPPA, S., YAMAMOTO, ME. and CACHO, MSRF., 1999b. Reproductive behaviour and ecology of two species of Cichlid fishes. In: AL. Val and VMF. Almeida-Val (eds.). Biology of Tropical Fishes. Manaus: INPA., p. 113-126.

GOULD, JL. and GOULD, CG., 1989. Sexual Selection. New York, Scientific American Library, p. 168-173.

HOWELL, DC., 1992. Statistical Methods for Psychology. California: Dexbury Press, 693.

HUNTINGFORD. F., 1979. Pre breeding aggression in male and female three-spined sticklebacks (Gasterosteus aculeatus). Aggres. Behav., vol. 5, p. 51-58.

KREBS, JR. and DAVIES, NB., 1996. Behavioural Ecology: An Evolutionary Aproach. Oxford: Blackwell Scientific Publications, 420.

LAMPECHT, J. and REBHAN, T., 1997. Factors influencing pair bond stability in convict cichlids (Cichlasoma nigrofasciatum). Behav. Proces., vol. 39, p. 161-176.

NICOLETO, PF., 1995. Offspring quality and female choice in guppy, Poecilia reticulata. Anim. Behav., vol. 49, p. 377-387.

ROGERS, W., 1995. Female choice predicts the best father in a biparental fish, the Midas cichlid (Cichlasoma citrinellum). Ethol., vol. 100, p. 230-241.

SABINO, J., 1999. Comportamento de peixes de riachos: métodos para uma abordagem naturalística. In: EP. Caramaschi, R. Mazzoni and PR. Perez-Neto (eds.). Ecologia de Peixes de Riachos. Serie Ecologia Brasiliensis. VI: UFRJ. Rio de Janeiro, Brasil, p. 183-208.

TAKEGAKI, T. and NAKAZONO, A., 1999. Reproductive behaviour and mate fidelity in the monogamous goby, Valenciennea longipinnis. Icthyol Resear., vol. 46, no. 2, p. 115-123.

WALTER, B. and TRILLMICH, F., 1994. Female aggression and male peace-keeping in a cichlid fish harem: conflict between and within the sexes in Lamprologus ocellatus. Behav. Ecol. Sociobiol., vol. 34, p. 105-112.

WICKLER, W. and SEIBT, U., 1985. Monogamy: an ambiguous concept. In: Patrick Bateson (ed). Mate Choice. London, Cambridge University Press, p. 33-47. 